\title{
Kampanye Kandidat Presiden Amerika Serikat dalam Meraih Simpati Para Pemilih
}

\author{
Aziz Taufik Hirzi \\ ABSTRACT \\ US presidential elections become one of the hottest issues in political world nowadays. \\ It draws attention not only from local federal countries, but also attracts international audiences \\ as the candidates from Democrats are challenging each other. From political communication \\ studies, the campaign stages of US presidential elections reflected a mature democratic political \\ system which stands on many humanity values, such as truth, honesty, fairness, and respect \\ for others. The issue toward candidate's cleanliness was predicted would be determiner for each \\ candidate whether or not they will move further in electoral process. People, or potential voters \\ will count on cleanliness more than any other else.
}

Kata kunci: kampanye, kandidat presiden, Amerika Serikat, 2007, simpati pemilih

\section{Pendahuluan}

\subsection{Latar Belakang}

Amerika Serikat sebagai salah satu negara adikuasa di dunia, dinilai oleh kalangan negaranegara barat dan sekutunya sebagai negara yang paling menjunjung kebebasan berbicara, kebebasan memilih, kebebasan pers, dan hak asasi yang dijamin sepenuhnya, sehingga dengan jaminan itu setiap warga negara bebas melakukan apa saja sepanjang tidak melanggar undangundang dasar dan falsafah negara yang dianut.

Dalam berbagai kegiatan atau peristiwa penting, tidak sedikit warga negara yang menaruh minat untuk mengikutinya. Salah satu di antaranya adalah kegiatan kampanye presiden yang diawali kampanye kandidat di lingkungan intern partai, kampanye akhir dalam usaha memenangkan pemilihan.
Dalam kampanye akhir, biasanya yang muncul adalah dua kandidat dari Partai Demokrat dan Partai Republik, dua partai besar yang secara tradisional senantiasa memerintah Amerika Serikat secara bergantian. Di samping itu, tidak tertutup kemungkinan munculnya kandidat lain dari kubu berbeda, seperti yang pernah dialami pada tahun 1980, ketika Jimmy Carter dari Partai Demokrat, Ronald Reagan dari Partai Republik didampingi oleh Anderson dari kelompok independen (sempalan dari Partai Demokrat).

Kampanye kandidat presiden biasanya mendapat perhatian besar dari khalayak, termasuk media yang dengan sengaja memanfaatkan/mengisi ruangan dan kolom media dengan berita tentang karakteristik dan program kandidat. Segala keterampilan, kelemahan, kasus, skandal, dan bahan berita yang dianggap menarik tidak luput dari pemberitaaan-pemberitaan. 
Masyarakat Amerika Serikat yang relatif memiliki kesadaran politik yang tinggi dibandingkan dengan masyarakat di negara-negara berkembang turut "meramaikan" suasana dan saatsaat kampanye. Saat-saat kampanye adalah saatsaat yang paling menentukan bagi kandidat. Kandidat benar-benar diuji kemampuannya dari mulai penampilannya, gaya bicara, materi program sampai pelaksanaanya apabila terpilih nanti. Kandidat yang tidak mampu meyakinkan massa pemilih dan para pendukungnya, atau kandidat yang terkena tuduhan karena skandal/kasus moral. Adalah kandidat yang memiliki kecenderungan reputasinya menurun.

Masyarakat Amerika Serikat cukup kritis dan paham terhadap kondisi kandidat. Jadi tidak heran jika pilihan mereka beralih kepada kandidat lain yang lebih terpercaya hanya karena alasan program yang kurang tidak meyakinkan dari calon ungulan sebelumnya. Sebagai contoh, pada tahun 1972, pendukung partai demokrat siap memenangkan George McGovern. Namun, pada saat-saat kampanye, tampaknya kurang meyakinkan, sehingga tidak sedikit pendukung McGovern membelot ke Partai Republik yang mencalonkan Richard Nixon untuk jabatan yang kedua kalinya. Kurang dari setengahnya para pendukung McGovern dari partainya yang menyatakan positif terhadapnya.

Untuk meraih simpati para pendukung dan menduduki jabatan terhormat itu ternyata tidak mudah. Kandidat dituntut kemampuannya untuk merumuskan dan menawarkan program yang andal kepada massa pemilih. Di samping itu, harus mampu beradu argumentasi program dengan saingannya di media-media secara terbuka, yang berarti bahwa kandidat itu tidak hanya cukup tampil dan terampil membuat program-program, tetapi juga dituntut kemampuannya untuk "mahir berbicara" (menyampaikan pidato dengan sistematis dan retoris), dan melakukan pendekatan persuasif dan komunikatif dengan massa.

Seorang kandidat presiden harus siap mental dan siap berkorban mengeluarkan sebagian dananya untuk membayar para "petugas kampanye": pemuka pendapat, manajer, sekretaris, sekuriti, dan para pembantu setianya, ditambah dengan biaya-biaya persiapan, konferensi pers, kunjungan ke berbagai daerah dan lembaga, biaya penyebarluasan di berbagai media, dan lain-lain.

Bantuan dari perangkat personel (petugas kampanye) sangat penting. Karena itu, jauh-jauh hari menjelang kampanye berlangsung, para kandidat sudah mempersiapkannya. Perangkat yang trampil, terutama para pemuka pendapat yang kharismatis, memiliki pengaruh besar dan manajer yang mampu mengelola pelaksanaan tugas-tugas kampanye sudah banyak dipesan oleh para kandidat.

Kompetisi tersebut, tidak asing lagi bagi bangsa Amerika Serikat yang memiliki tingkat sosial ekonomi yang lebih baik dari negara-negara berkembang, meskipun kandidat-kandidat itu akhirnya kalah atau gagal meraih kemenangan. Apabila dilihat dari segi materi, pihak yang kalah. Tampaknya rugi besar, namun untuk ukuran sosial ekonomi Amerika, itu suatu hal biasa.

\subsection{Identifikasi Masalah dan Tujuan Penulisan}

Apabila dirinci masalah yang akan dikemukakan dalam makalah ini meliputi:

(1) Apakah tujuan dan kegunaan kampanye itu bagi kandidat presiden Amerika Serikat? Bagaimanakah proses pelaksanaannya?

(2) Upaya apakah yang dilakukan para kandidat presiden Amerika Serikat dalam meraih simpati para pemilih?

(3) Sejauhmanakah pengaruh kampanye kandidat presiden terhadap masyarakat Amerika Serikat, terutama para pemilih?

\section{Pembahasan}

\subsection{Kampanye Pemilihan Presiden}

Kampanye adalah serangkaian tindakan komunikasi yang terencana dengan tujuan menciptakan efek tertentu pada sejumlah besar khalayak yang dilakukan secara berkelanjutan pada kurun waktu tertentu (Rogers dan Storey dalam Venus, 2004:7).

Sebagian masyarakat Amerika menganggap 
bahwa kampanye pemilihan itu sebagai upaya yang rumit untuk membuat propaganda yang ditujukan kepada pemberi suara yang potensial. Namun, Jacques Ellul berargumentasi bahwa jangka waktu yang terbatas untuk kampanye politik hampir tidak cukup untuk propaganda yang penuh. Selanjutnya, ia menyatakan bahwa tidak mengherankan propaganda seperti itu hanya sedikit pengaruhnya, sebab tidak ada teknik besar propaganda yang dapat efektif dalam kampanye yang terbatas. Dalam setiap pemilihan, terdapat unsur propaganda (terutama dengan komuinikasi organisasi melalui partai politik), tetapi sifat dasar kampanye kontemporer terletak pada upaya untuk memersuasi melalui periklanan massa (komunikasi massa) dan retorik (komunikasi interpersonal), bukan pada propaganda (Dan Nimmo, 1989:219).

Kampanye bagi setiap peserta pemilu, termasuk pemilihan Presiden di Amerika Serikat, adalah suatu hal yang penting dalam usaha memeroleh simpati dan dukungan massa sebanyakbanyaknya, sehingga dengan dukungan itu seorang kandidat bisa memenangkan pemilihan. Kemudian, pemilihan dikatakan sukses apabila berlangsung tertib, jujur dan adil, termasuk pihak yang kalah tidak merasa dirugikan.

"Kebersihan pemilihan presiden" relatif, bagaimanapun rupa-rupa masalah pasti ada, hanya kadarnya berbeda. Pengalaman pahit pernah dialami Amerika Serikat ketika terjadi skandal Watergate yang terungkap secara lengkap pada tahun 1974, dua tahun setelah pemilihan Presiden.

Skandal Watergate muncul sebagai ungkapan rasa tidak puas masyarakat Amerika Serikat terhadap kecurangan Nixon pada pemilihan tahun 1972. Ketidakpuasan ini muncul tidak hanya di kalangan penentangnya Partai Demorat, tetapi juga di kalangan Partai Republik, partainya Nixon, yang semula mendukung berbalik menjadi menentang.

Skandal ini sangat memukul Nixon dan meruntuhkan moral dan kepercayaan khalayak terhadap Partai Republik. Akhirnya, ia mundur menyusul tekanan yang sangat kuat dari kongres. Ia digantikan oleh wakilnya Gerald Ford.

Menghadapi pemilihan presiden berikutnya, tahun 1976, Ford dan Partai Republik berbenah diri dan berusaha mengembalikan citra positif dalam meningkatkan kepercayaan masyarakat. Namun pada saat itu, sebagian besar masyarakat nampaknya belum mempercayai sepenuhnya, sehingga pada saat pemilihan presiden melawan Jimmy Carter dari Partai Demokrat, ia kalah tipis. Meskipun peristiwa Watergate dianggap sangat memalukan, perjuangan kubu Partai Republik tidak pernah surut. Para politisinya yang terkenal ulet dan tegas-tegas, membuat rakyat Amerika Serikat kembali membuat perhitungan, terbukti sejak kekalahan Jimmy Carter tahun 1976, pemerintahan Amerika Serikat beberapa kali berada di tangan Partai Republik dengan tokohnya masing-masing: Ronald Reagan sebagai Presiden dan George Bush sebagai Wakil Presiden (1980-1988); George Bush Sr. (1988-1992); Clinton dari Partai Demokrat (19922000); dan George Bush Jr. (2000-2008).

Kemenangan Partai Republik ditopang oleh fanatisme yang tinggi, gerakan yang agresif, dan konsolidasi internal partai yang rapih, dan kerja tim manajemen kampanye yng militan, yang mampu membangkitkan, menggairahkan, dan meyakinkan rakyat Amerika Serikat.

\subsubsection{Tujuan dan Kegunaan Kampanye}

Untuk memperjelas arahan kampanye, agar kampanye itu benar-benar mengenai sasaran, para kandidat, baik yang berasal dari partai politik maupun yang independen, secara umum memiliki tujuan yang sama:

(1) Membangkitkan kesetiaan alami para pengikut suatu partai, agar mereka merasa yakin untuk memilih kandidat yang ditampilkan partai yang didukungnya.

(2) Menjajagi warga negara yang tidak terikat pada suati partai atau mengidentifikasi kelompok independen untuk mengukur sejauhmana partisipasi mereka terhadap pemilihan presiden. Dalam penjajagan ini, kandidat presiden berusaha mengalihkan perhatian dan sikap kelompok independen kepada sikap mendukung kandidat presiden dari partai tertentu.

Bagi kandidat presiden, kampanye ini sangat penting dan berguna untuk memperkenalkan 
dirinya kepada khalayak, terutama pengalaman perjuangannya; melihat dari dekat situasi dan kondisi massa, massa pendukung atau lawan. Dengan cara itu, kandidat presiden bisa setiap saat membuat langkah-langkah yang konkret untuk menghadapi berbagai kemungkinan yang terjadi. Kegunaan lain adalah sebagai uji keterampilan kandidat dalam berdebat dengan sesama kandidat, berbicara di hadapan umum dan berdiskusi dengan pihak pendukung atau lawan.

Dengan kampanye, masyarakat Amerika Serikat dapat melihat setiap gagasan yang timbul, wawasan berpikir, prakiraan dedikasi dan perhatian kandidat dalam merespons aspirasi masyarakat. Penampilan dan penampakan itu akan berpengaruh terhadap pengumpulan suara dukungan. Bagaimanapun, masyarakat Amerika akan memperhitungkan kualifikasi, kualitas, dan prestasi kandidat.

\subsubsection{Proses Pelaksanaan Kampanye}

Kandidat presiden diberi keleluasaan untuk melaksanakan kampanye sesuai dengan jadwal yang telah diatur oleh kandidat presiden dan partainya serta pemerintah.

Yang pertama dilakukan adalah kampanye dalam usaha memenangkan pemilihan pendahuluan di lingkungan partainya sendiri. Setelah berhasil, terus melaju ke pemilihan berikutnya bersaing melawan kandidat dari partai lain atau kalangan independen.

Para kandidat presiden biasanya didampingi oleh petugas lain yang bertindak sebagai penasehat, pemuka pendapat, manajer kampanye, sekretearis, sekuriti, dan para pembantu lain dari lingkungan partainya sendiri.

Kampanye itu dilakukan berhari-hari dan cukup panjang, bahkan kadangkala melelahkan. Di samping itu, biayanya sangat besar untuk memenuhi segala kebutuhan. Itulah risiko kandidat Presiden Amerika Serikat.

Kampanye dapat dilakukan di berbagai tempat, tempat tertutup dengan jumlah peserta yang hadir relatif lebih banyak atau di tempat mana saja sesuai dengan kebutuhan.

Yang terlibat dalam pelaksanaan kampanye, selain kandidat presiden, pendukung, dan petugas kampanye, berbagai pihak pun biasanya ikut serta "meramaikan suasana kampanye", seperti lembagalembaga penelitian dan media massa yang sengaja mencari tahu perkembangan kampanye dan jumlah suara dukungan atau tolakan melalui angket/ kuesioner yang telah disebarkan kepada para penghadir kampanye. Hasil penelitian yang biasanya disebarkan secara terbuka itu cukup menarik perhatian berbagai pihak, termasuk “pelajaran” bagi kandidat presiden.

\subsection{Strategi Kandidat Presiden dalam Memenangkan Pemilihan}

Masing-masing kandidat presiden, memiliki strategi dalam upaya memenangkan pemilihan dan strategi itu tertuang dalam rencana kampanye, mulai dari penentuan waktu, tempat, acara, dan massa yang hadir. Selain itu, program yang ditawarkan adalah bagian yang sangat penting dalam kampanye kandidat presiden.

\subsubsection{Kreasi Kandidat Presiden dalam Memenangkan Pemilihan}

Kreasi kandidat sangat penting dalam menentukan keberhasilan memenangkan pemilihan, karena kandidat yang kreatif itulah biasanya yang paling banyak menarik perhatian massa, tidak hanya para pendukung tetap dan setia, tetapi juga pendukung "musiman" dan pihak lawan (pesaing).

Seorang kandidat dituntut kemampuannya untuk berbicara di hadapan lapisan kelompok masyarakat dengan tema-tema umum dan tematema khusus yang sesuai dengan situasi dan kondisi khalayak. Sebagai contoh, John Fitzgerald Kennedy, pada tahun 1960 mengemukakan janjinya dengan tema sentral New Frontier. Tema tersebut cukup berkesan dan menarik perhatian massa terutama para kawula muda dan pembaharu. Kennedy yang tampak masih muda (kala itu berusia 41 tahun), energik, cerdas, tampan, dan perkasa tidak luput pula menarik perhatian wanita-wanita cantik. Pidatonya sangat memukau, penampilan pribadinya yang mengagumkan, tegar, tegas, terkesan ramah, dan murah senyum, membuat 
simpati massa pemilih.

Pada tahun 1964, Lyndon B. Johnson, mengangkat tema Great Society yang menunjukkan kepada bangsa Amerika, bahwa negara Amerika Serikat adalah negara besar yang mampu berperan dalam percaturan dunia, terbukti sejak ia terpilih, pengiriman tentara Amerika Serikat ke Vietnam dilakukan secara besar-besaran.

Pada tahun 1976, Jimmy Carter mengemukakan tema kampanye Leadership for a change yang memiliki kesan demokratis dan fleksibel. Kepemimpian Carter untuk seluruh dan atas kepercayaan Amerika Serikat. Sementara tema yang dikemukakan Gerald Ford pada tahun yang sama adalah He's made us proud again memberi kesan selah-olah ingin memperbaiki cira negara dari musibah yang telah dialami dan memalukan, yakni peristiwa Watergate.

Lain halnya dengan bakal kandidat presiden Amerika Serikat 2008-2012. Bakal kandidat dari kedua kubu, Partai Republik dan Partai Demokrat menyampaikan gagasan-gagasan yang sangat kontras. Kubu dari Partai Republik seperti McCain, Romney, dan Rudolph Giuliani mendukung dengan tegas "pendudukan" Amerika Serikat di Irak, sementara dari Partai Demokrat seperti Barrack Obama, Hillary Clinton, dan John Edwards berpandangan perlu ditariknya pasukan Amerika Serikat dari Irak secepat mungkin (sesuai dengan keinginan sebagian besar Amerikas Serikat dalam setiap jajak pendapat).

Selain itu, McCain (Partai Republik) akan berusaha bersifat moderat atas pelayanan imigrasi. Sementara Obama (Partai Demokrat) akan meningkatkan pelayanan kesehatan, mengatasi pengangguran, di samping berpandangan hampir sama dengan McCain tetntang imigrasi. Bakal kandidat ini pun berusaha merangkul tokoh berpengaruhn seperti Edward (Teddy Kennedy), yang kemudian terang-terangan mendukung Obama. Yang kontras lagi adalah, ia akan memberangus kelompok ekstrem Islam radikal. Obama, sebaliknya, akan menggelar pertemuan komunitas Muslim se-Amerika bahkan se-dunia.

Tema-tema besar/slogan indah dari kedua kubu itu belum tampak. Tapi dari beberapa gagasan, tersirat kira-kira bakal arah kebijakan mereka jika terpilih kelak. Gagasan-gagasan itu muncul berdasarkan analisis team manajemen kampanye setelah mempertimbangkan hasil jajak pendapat lembaga-lembaga survei dan pengamatan situasi dan kondisi di lapangan. Gagasan-gagasan tersebut dibahas sedemikian rupa untuk menarik simpati dan perhatian para pemilih, karena pemilih di Amerika Serikat yang relatif memahami dan memiliki tingkat kesadaran politik yang tinggi, akan percaya apabila gagasan yang digelontorkan para bakal kandidat itu dianggap jelas dan meyakinkan. Rakyat Amerika tidak ingin membeli kucing dalam karung.

Di samping itu, isu "bersih diri" akan menentukan terpilih/tidaknya bakal kandidat. Sebagai contoh, antara lain, Kennedy (1960) dan Clinton (1992 dan 1996) dari Partai Demokrat menang karena mereka dianggap penganut Nasrani yang taat, meski belakangan setelah lengser diketahui memliki hubungan asmara. Gary Hart (1984) gugur di tengah jalan karena isu asmara dengan Donna Rice, dan McGovern (1972) yang hampir terpilih, tersisih karena isu keturunan Polandia. Isu bersih diri ini umumnya dipublikasikan oleh tim media kampanye masingmasing. Sementara pihak lawan, mencoba membongkar kelemahan saingannya dengan mencoba melakukan kampanye negatif.

Sekelompok pemilih bisa beralih pilihan, manakala isu negatif cukup memberi keyakinan. Sebaliknya kelompok lain bisa bertahan, manakala kandidat itu dianggap representasi kelas sosialnya dan tidak terpengaruh isu negatif. Pemilih ini boleh jadi merupakan ekspresi loyal terhadap figur atau partai tertentu yang menjadi idolanya. Nicholas O'Shaughnessy (dalam Nursal, 2004:53) mengemukakan bahwa

A political issue is not merely a product to be merchandised but rather a vibrant value symbol connecting with an individual's sense of who and what he or she is at deepest level.

Tema-tema kampanye yang dibuat oleh kandidat presiden, merupakan tema pilihan mereka yang dianggap paling komunikatif dengan massa. Di samping itu, para kandidat presiden berusaha 
mengadakan pendekatan dengan berbagai pihak, seperti dengan pejabat-pejabat tinggi, pengusaha, petani, buruh pabrik, peternak, guru, seniman, olahragawan, pemilik media massa dan jurnalis. Mereka diharapkan menjadi pendukung setia yang dapat menambah suara bagi keunggulan kandidat.

Dalam melakukan kegiatan itu, kandidat bisa mendatangi langsung mereka/berbicara dengan tatap muka atau bisa juga mengundang mereka ke tempat-tempat tertentu yang telah dipersiapkan dan diperhitungkan, seperti hotel, arena rekreasi terbuka, restoran, dan tempat lain yang memungkinkan mereka bisa datang.

Dalam kampanye itu, para bakal kandidat/ kandidat senantiasa berusaha untuk menjaga citra. Menampilkan yang terbaik, yang penuh dengan etika dan moral. Komunikasi politik yang persuasif dibangun hingga menarik minat dan perhatian para pemilih. Obama mengunjungi keluarga Kennedy menyiratkan bahwa kulit hitam pun bisa bekerja sama dengan kulit putih, sementara Hillary mengunjungi kaum hispanik menunjukkan bahwa ia sangat perhatian kepada orang-orang kulit berwarna dan keturunan imigran.

Kegiatan kampanye ini biasanya memerlukan biaya yang sangat besar, seperti yang pernah dialami oleh GeorgeMcGovern tahun 1972, ia mengeluarkan biaya 30 juta dollar Amerika hanya untuk kalah. Jumlah itu melebihi jumlah yang diatur dalam Undang-Undang Kampanye Pemilihan Federal tahun 1974 dan 1976, di mana seorang kandidat Presiden Amerika Serikat tidak boleh mengeluarkan lebih dari 20 juta dollar Amerika untuk kepresidenan.

\subsubsection{Peran "Petugas Kampanye" dalam Pemilihan Presiden}

"Petugas kampanye" adalah orang-orang yang membantu pelaksanaan kampanye kandidat presiden dalam upaya memenangkan pemilihan. Mereka adalah pemuka pendapat, manajer, sekretaris, sekuriti dan para pembantu lain yang dipercaya. Pemuka pendapat diminta pandangannya untuk memberikan pokok pikiran, pemecahan masalah, saran-saran, dan nasihat serta petunjuk dan informasi yang diperlukan, untuk mengetahui apa yang harus dilakukan atau untuk memperkuat keputusan yang telah dibuat.

Pemuka pendapat adalah orang yang sangat disegani, dihormati, dan sangat berpengaruh. Karena itu, jauh-jauh hari sebelum kampanye berlangsung, banyak pihak yang memesannya, karena kemampuannya dalam meyakinkan orang.

Pemuka pendapat meneruskan informasi politik dari media berita kepada masyarakat umum. Dalam arus komunikasi dua tahap ini, "gagasan" sering mengalir dari radio dan media cetak kepada pemuka pendapat dan dari mereka kepada penduduk yang kurang aktif(Dan Nimmo, 1989:40).

Charles Wright dalam penelitiannya tentang karakteristik dan peranan pemuka pendapat mengemukakan sebagai berikut:

(1) Pemuka pendapat terdapat pada struktur sosial yang menunjukkan bahwa pengaruh personal mengalir bukan hanya dari "atas ke bawah" di dalam masyarakat, tetapi juga secara horisontal di dalam kelas-kelas sosial atau status kelompok lainnya.

(2) Pemuka pendapat diketahui sebagai orangorang yang waspada, tertarik dan aktif secara politis.

(3) Pemuka pendapat lebih diterpa kampanye media massa daripada yang bukan pemuka pendapat.

(4) Pemuka pendapat telah menggunakan gagasan-gagasan dan informasi yang diperoleh dari media massa dalam nasehat dan penerangan yang mereka sampaikan kepada para pengikutnya (Wright, 1985:100).

Beberapa kelebihan itulah yang sangat menarik bagi kandidat presiden untuk memanfaatkan pemuka pendapat pada saat-saat yang diperlukan.

Untuk mengatur "lalu lintas" kegiatan kampanye itu pun diperlukan manajer tangguh yang mampu mengarahkan acara/program kampanye bagi kepentingan kandidat. Tugas manajer ini biasanya didampingi sekretaris manajer dan para pembantu lain yang dipercaya.

Manajer dan petugas lainnya (bawahannya) Harus mampu mengenal medan kampanye, baik yang digunakan oleh kandidat presiden itu sendiri maupun saingannya. Pengenalan medan yang 
dilakukan dengan survei pendahuluan menjadi bahan berharga bagi kandidat, sehingga rencanarencana kampanye yang didukung oleh para petugas kampanye tadi dapat dijadikan sebagai bahan untuk menganalisis situasi yang berkembang.

Selain itu, sekuriti merupakan faktor utama bagi keselamatan kandidat. Fasilitas sekuriti yang diberikan pemerintah sangat terbatas, selebihnya terserah kandidat. Namun, tugas, status, dan kewenangannya bebeda. Sekuriti yang diminta/ ditunjuk oleh kandidat bersifat sangat intern, semata-mata melindungi keselamatan kandidat, di samping memata-matai yang bersifat mencurigakan.

Petugas lain, seperti petugas teknis dan operasional, tidak kurang pentingnya bagi kelangsungan kampanye dan keberhasilan kandidat.

\subsubsection{Pemanfaatan Media Komunikasi bagi Kegiatan Kampanye}

Media Komunikasi dalam kegiatan kampanye dapat dijadikan sebagai alat untuk menyampaikan isi politik dan alat pendidikan politik serta propaganda poltik. Alexi menyatakan bahwa perilaku politik dan orientasi politik dapat dipelajari dari media massa apabila materi politik cukup tersedia dalam media tersebut dan apabila audiensi sendiri mau memperhatikan terhadap materi tersebut. (Sumarno, 1989:86)

Media komunikasi dapat membantu melipatgandakan pesan-pesan komunikasi yang sampai kepada masyarakat, baik dalam skala regional, nasional, maupun internasional.

Media komunikasi memiliki peranan yang kuat dalam upaya memberikan berbagai informasi baik untuk mencerahkan maupun untuk menyesatkan. Dalam istilah McNair, disebut the media's hegemonic role. Media di Amerika Serikat, yang umumnya "berjarak" dengan elit politik, berupaya untuk membuat berita yang memiliki nilai berita. Karena itu, para team manajemen kampanye berupaya mendekati media dengan menyediakan informasi terbaik darinya.

Megingat media komunikasi itu memiliki arti penting dan sangat strategis, maka setiap kandidat Presiden Amerika Serikat senantiasa menggunakan media sebagai sarana pendukung kampanye, antara lain radio, televisi dan suratkabar.

Kampanye di radio, Tony Schwartz, dalam bukunya The Responsive Chord melaporkan bahwa rata-rata orang Amerika mendengarkan radio selama 21 jam seminggu; ketika bekerja, dalam perjalanan ke dan dari tempat bekerja dan pada waktu-waktu senggang (Dan Nimmo, 1989:224).

Minat dan perhatian masyarakat Amerika Serikat terhadap radio "memancing" para kandidat presiden untuk menggunakan radio sebagai salah satu media kampanye. Media ini memiliki keuntungan tertentu yang melebihi sarana komunikasi lain. Media ini lebih murah daripada televisi atau surat langsung, namun sasarannya terbatas pada jenis pemilih yang kemungkinan besar menanggapi. Karena itu, berbagai stasiun radio memiliki khalayak khusus.

Pada saat-saat kampanye, para kandidat mulai giat menggunakan radio sebagai salah satu media kampanye, misalnya pada tahun 1972, Richard Nixon yang memanfaatkan 30 menit untuk serangkaian pembicaraan radio yang mengajak para pemilih untuk mendukungnya.

Di samping pembicaraan formal dalam radio, juga siaran "iklan politik" yang berisi penawaranpenawaran program. Cara lain untuk memperluas jangkauan, pesan-pesan/pernyataan kandidat direkam dulu, kemudian hasil rekaman berupa "kisah berita" kandidat dikirimkan melalui pos ke stasiun-stasiun radio di kota-kota kecil untuk selanjutnya disiarkan dalam siaran berita tetapnya.

Kampanye di televisi. Kampanye di televisi tumbuh subur dalam tiga dasawarsa terakhir, terbukti minat dan perhatian massa terhadap eksistensi televisi terus meningkat. Kampanye ini sebenarnya sangat mahal. Namun, bagi seorang kandidat presiden di Amerika Serikat tidak menjadi masalah, seperti menjelang pemilihan presiden tahun 1968, lebih dari 28 juta dollar Amerika Serikat dikeluarkan untuk kampanye, sebagian besar dari jumlah itu digunakan untuk biaya kampanye di televisi.

Mengingat biaya kampanye itu sangat mahal, 
maka materi kampanye perlu diperhitungkan; ringkas, jelas, tersistematis dan tepat sasaran. Misalnya, pada tahun 1960-an, tekanan dalam kampanye televisi ialah pada "pembuatan citra", yakni:

Penggunaan media untuk memproyeksikan atribut-atribut terpilih dari kandidat.

Pembuatan video edngan strategi yang jelas dan penampilan pribadi yang menarik.

Penggunaan format untuk program hiburan seperti komersial spot (menampakkan hal yang dapat ditawarkan) selama 20 detik, 30 detik, atau 60 detik sebagai pengganti pidato televisi selama setengah jam.

Film dokumenter tentang pribadi kandidat terutama kegiatan-kegiatan sosial/kemanusiaan selama setengah jam.

Penyampaian pesan yang mirip dengan "iklan politik" itu diharapkan mampu memberi informasi ringkas kepada para pemilih tentang pokok masalah yang ditawarkan, bahkan tidak tertutup kemungkinan cara-cara ini bisa lebih ampuh daripada dengan pidato-pidato panjang yang kadangkala menjenuhkan. Karena itu, pemrograman acara merupakan hal yang penting dan menjadi perhatian kandidat dan para petugas kampanye.

Kampanye di suratkabar. Setiap kampanye yang tidak mungkin dilakukan di radio dan televisi, akan dilakukan di suratkabar. Suratkabar sebagai sarana komunikasi dalam kegiatan kampanye mampu membuat tulisan-tulisan panjang dalam berita, editorial, dan iklan. Semua itu membantu pembinaan citra dan penyajian masalah yang dikemukakan kandidat.

Dalam suatu studi tentang peliputan berita dalam pemilihan presiden tahun 1968 oleh harianharian metropolitan, Doris Graber menemukan bahwa fokus perhatian terhadap citra pribadi jauh lebih banyak daripada penyajian masalah/masalah pokok (Dan Nimmo, 1989:230).

Para kandidat menyadari semua itu. Karena itu, ia berusaha melakukan pendekatan-pendekatan kepada suratkabar agar berkenan memuat "catatancatatan" positiftentang pribadi kandidat. Pemuatan tentang kredibilitas, watak, gaya, dan reputasi kandidat pada bagian berita, editorial, dan iklan akan sangat penting artinya bagi kandidat dalam meyakinkan rakyat Amerika, khususnya para pemilih pendukung.

Kampanye di suratkabar melalui iklan, selain digunakan oleh kandidat untuk menawarkan program-program ringkasnya, juga banyak dimanfaatkan oleh para pendukung dengan memuat daftar nama pendukung. Sederetan nama dari berbagai lapisan dan kelompok masyarakat, termasuk mereka yang dianggap memiliki pengaruh besar dari kalangan pemilih, dicantumkan. Pencantuman itu ada yang atas dasar keinginan sendiri dan ada juga yang sengaja diajak dan mau.

Studi yang lebih komprehensif, yang diselenggarakan di 23 negara bagian selama pemilihan tahun 1970, mengungkapkan bahwa kurang dari setengahnya, pernyataan iklan politik dalam suratkabar mengacu kepada masalah bukan kepada kandidat atau kepada afiliasi partainya (Dan Nimmo, 1989:231).

Negara Amerika Serikat yang liberal, ternyata masih juga memerhatikan "citra positif" atau kualitas moral individu. Seorang kandidat yang dinyatakan tidak bersih, seperti yang dialami Gary Hart menyebabkan ia harus mundur dari pencalonan.

Di samping radio, televisi, dan suratkabar, kampanye juga melalui surat langsung, poster, spanduk, selebaran brosur, telepon, dan lain-lain

\subsection{Pengaruh Kampanye dan Respons Pemilih}

Dampak mendasar dari kampanye adalah memperkuat keyakinan para pemilih pendukung dan usaha para kandidat/petugas kampanye untuk meraih simpati massa mengambang dan membelotkan perhatian pendukung lawan agar menjadi kawan.

Kandidat yang mampu menampilkan citra dirinya dan program yang disertai standar disertai dukungan para juru kampanye, yang terdiri dari para ahli atau orang yang berpengaruh, memiliki kecenderungan yang kuat dalam meraih simpati massa.

Rakyat Amerika sangat kritis dan selektif dalam memilih calon dan menyaring materi-materi 
kampanye, sehingga setiap orang yang tampil hanya sekadar coba-coba, tidak didukung oleh kriteria yang memenuhi syarat bisa kerepotan. Rakyat Amerika suka terus terang dan mampu mengungkap berbagai kelemahan kandidat.

Respon mereka terhadap kegiatan kampanye cukup baik. Kampanye adalah ajang adu argumentasi orang-orang terpilih, ajang rebutan kursi empuk, dan ajang pesta demokrasi yang mampu menyalurkan berbagai kepentingan dan aspirasi rakyat. Penampilan kandidat yang beragam, ada yang menarik, ada yang tidak menarik; ada yang meyakinkan dan ada yang kurang meyakinkan, menyebabkan respon mereka kepada kandidat berbeda. Di sinilah penampilan dan keterampilan kandidat benar-benar diuji. Karakter pemilih/pemberi suara responsif tidak tetap, selalu berubah mengikuti waktu dan bergantung pada peristiwa-peristiwa politik yang terjadi.

Pomper menyebutkan bahwa pemberi suara responsif memiliki ciri-ciri sebagai berikut:

(1) Dipengaruhi oleh karekater sosial dan demografis. Pengaruh yang pada hakikatnya merupakan atribut permainan itu tidak bersifat menentukan.

(2) Memiliki kesetiaan kepada partai, tetapi afiliasi ini tidak menentukan perilaku pemilihan. Ikatan kepada partai lebih rasional daripada emosional.

(3) Lebih banyak dipengaruhi oleh faktor-faktor jangka pendek yang penting dalam pemilihan umum tertentu daripada kesetiaan jangka panjang kepada kelompok atau kepada partai yang lebih penting dari semua pemilihan umum (Dan Nimmo, 1989:194).

Sebagai akibat dari diselenggarakannya kampanye, berbagai media ikut terlibat. Media secara kontinyu memuat pidato politik para kandidat. Media yang independen akan memuat pidato-pidato politik pra kandidat dari partai mana pun. Selain itu, suara-suara dukungan, tolakan massa dari berbagai kubu, juga menghiasi halaman dan ruangan media.

Sementara itu, pers di Amerika Serikat, secara tradisional selalu menampilkan tokoh-tokoh politik yang berpengaruh yang dianggap mewakili kepentingan partai politik, seperti penampilan goldwater yang mewakili Partai Republik dan johnson yang mewakili Partai Demokrat (Floyd, 1970:91).

Tokoh-tokoh itu pada tahun 1960-an, sangat berpengaruh dan memiliki ciri-ciri kepemimpinan yang kharismatis, sehingga dengan penampilannya itu mampu meraih simpati para pemilih. Pada masa kampanye itu pula, massa pemilih mengadakan konsolidasi, menggalang persatuan, dan menentukan sikap yang kompak untuk memilih kandidat yang dianggap paling tepat. Massa pendukung pemilih itu biasanya mengelompok, seperti diungkap dari hasil penelitian "pemilih secara kelompok", bahwa orang yang berada dalam gereja, keluarga, klub-klub sosial, dan kelompok kelembagaan yang sama cenderung untuk memilih atau memberikan suara yang sama (Wright, 1985:98)

Tidak ketinggalan, kalangan pengusaha media elektronik, media cetak, tukang spanduk, poster, brosur, dan pengusaha-pengusaha kecil lainnya akan memperoleh keuntungan dari hasil orderan sarana kampanye.

\section{Kesimpulan}

Kampanye, bagi setiap kandidat presiden, adalah suatu kegiatan penting dalam upaya memperoleh simpati dan dukungan massa sebanyak-banyaknya, sehingga dengan dukungan itu seorang kandidat presiden mampu memenangkan pemilihan. Setiap kandidat disyaratkan berlaku jujur, agar kampanye berlangsung aman, tertib, dan lancar. Setiap pelanggaran yang dilakukan pihak tertentu, seperti yang pernah dilakukan Nixon pada pemilihan presiden tahun 1972, yang terkenal dengan peristiwa Watergate, merupakan pengalaman pahit yang menurunkan kepercayaan massa terhadapnya, sekaligus mengganggu kelancaran pemilihan presiden, padahal "citra bersih/positif" diri kandidat merupakan bahan pertimbangan dan perhitungan utama para pemilih.

Kampanye yang dilakukan para kandidat pada 
dasarnya memiliki tujuan yang sama, yaitu membangkitkan kesetiaan alami para pendukung partai dan menjajagi serta mengajak warga negara untuk memilih kandidat presiden dari partai tertentu. Bagi kandidat presiden, kampanye itu sangat penting dan berguna untuk memperkenalkan dirinya kepada khalayak, sehingga khalayak tahu identitas (ringkas) kandidat. Kegunaan lain adalah sebagai uji diri keterampilan kandidat dalam berbicara di hadapan umum, berdebat dengan sesama kandidat, dan berdiskusi dengan pihak pendukung atau lawan.

Kandidat presiden melaksanakan kampanye secara bertahap, yang diawali dari kampanye pemilihan pendahuluan (primary) di lingkungan partainya sendiri sampai kampanye akhir memperebutkan kursi presiden dengan melawan saingannya dari partai lain atau kelompok independen. Kampanye ini dilakukan berhari-hari, melelahkan, membutuhkan dana yang sangat besar, dan tenaga yang cukup, serta personel/ petugas kampanye yang memadai.

Untuk memenangkan pemilihan, setiap kandidat memiliki dan membuat strategi yang dianggap paling baik untuk diterapkan. Sebagai contoh, setiap kandidat sengaja menampilkan gagasan dan tema-tema, atau slogan kampanye yang menjadi trade mark-nya. Strategi lain adalah dengan melakukan pendekatan-pendekatan personel secara persuasif kepada (mendatangi) berbagai lapisan dan kelompok masyarakat, dan mengundang mereka ke tempat-tempat tertentu. Pada momen ini diadakan dialog dalam suasana santai dan penuh keakraban.

Dalam melaksanakan kampanye, kandidat tidak sendirian. Ia dibantu petugas kampanye yang senantiasa mendampinginya. Ia senantiasa berkonsultasi dengan pemuka pendapat, memperhatikan pokok-pokok pikiran mereka, petunjuk, informasi, saran, dan nasihatnya. Ia pun dibantu oleh manajer kampanye yang mengatur lalu lintas dan pemrograman kampanye, di samping para pembantu lain yang dipercaya.

Dalam usaha memperluas jaringan pengaruh, para kandidat pun memanfaatkan media komunikasi sebagai alat untuk menyampaikan isi, isu politik, dan alat pendidikan politik, serta propaganda politik. Untuk itu, radio, televisi, surat kabar, majalah, telepon, surat langsung, dan media lain yang dianggap memadai, tidak lepas dari perhatian para kandidat. Penyajiannya bisa rupa-rupa, antara lain, pidato-pidato politik dan iklan politik. Media komunikasi itu sangat efektif, terutama dalam penampilan citra kandidat. Kandidat yang mampu menampilkan cuitra dirinya dan program yang menarik memiliki kecenderungan yang kuat dalam meraih pemilih atau simpati massa. Massa pemilih di Amerika Serikat sangat kritis, selektif, dan responsif.

Sebenarnya, respon mereka terhadap kegiatan kampanye cukup baik. Mereka menganggap bahwa kampanye adalah ajang adu argumentasi orangorag terpilih dan ajang pesta demokrasi yang mampu menyalurkan berbagai kepentingan dan aspirasi rakyat. Di samping itu, sebagai akibat diselenggarakannya kampanye, berbagai media ikut terlibat memeriahkan penyelenggaraan kampanye. Baik media cetak, mapun media elektronik, dan media lainnya, salah satu kegiatannya adalah ikut membantu sekaligus mengkritisi kandidat dalam penyebarluasan pengaruh.

\section{Daftar Pustaka}

Arpan, Floyd G., Ruchady S., 1970. Wartawan Pembina Masyarakat. Bandung: Binatjipta.

Denton, Robert E., 2000. Political Communication Ethics, An Oxymoron. London: Praeger.

McNair, Brian, 2003. An Introduction to Political Communication. London: Routledge.

Nimmo, Dan, 1989. Komunikasi Politik: Komunikator, Pesan, dan Media. Penyunting Jalaluddin Rakhmat. Bandung: Remadja Karya.

1989. Komunikasi Politik: Khalayak dan Efek. Penyunting Jalaluddin Rakhmat. Bandung: Remadja Karya. 
Nursal, Adman, 2004. Political Marketing: Strategi Memenangkan Pemilu. Jakarta: Gramedia.

Sumarno, AP. 1989. Dimensi-dimensi Komunikasi Politik. Bandung: Citra Aditya Bakti.

Venus, Antar, 2004. Manajemen Kampanye. Bandung: Simbiosa Rekatama Media.
Wartella, Ellen dan D. Charles Whitney. 1998. Media Making: Mass Media in A Popular Culture. New Delhi: Sage Publications.

Wright, Charles R. 1985. Sosiologi Komunikasi Massa. Penyunting Jalaluddin Rakhmat, Bandung: Remadja Karya. 
